\title{
Cup Seal Device
}

National Cancer Institute

\section{Source}

National Cancer Institute. Cup Seal Device. NCI Thesaurus. Code C50165.

A circular seal with a depressed center and raised sealing lips. They are designed to contain high pressure in one direction but not the other. 